\title{
eudaimonia
}

Journal for Legal, Political and

Social Theory and Philosophy

No. 5 - 2021.

Published by

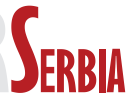

Journal for Legal, Political and

Social Theory and Philosophy

JUDICIAL AVENUES FOR UPHOLDING

THE INTERNATIONAL RULE OF LAW:

THE DOWNING OF MH17 CASE

Mina Radončić

Pages: $5-36$ 

Mina Radončić ${ }^{*}$

\section{JUDICIAL AVENUES FOR UPHOLDING THE INTERNATIONAL RULE OF LAW: THE DOWNING OF MH17 CASE}

The article seeks to identify the means in which key principles of the international rule of law are applied in practice. It postulates that the plurality of available legal remedies fosters the international rule of law development. The article evaluates the ongoing and potential legal proceedings against States in relation to the 2014 downing of flight MH17 and their interplay.

With the exception of the individual and the Dutch inter-State application, three international bodies are currently tackling the dispute from a perspective wider than the MH17 incident - namely, the situation in Eastern Ukraine (and Crimea). The objective of this article is to showcase the different efforts to bring justice by ramifying the MH17 case within them. The article chiefly focuses on the ongoing proceedings seeking State responsibility - the International Court of Justice (ICJ), and the European Court of Human Rights (ECtHR).

Key words: ECtHR, ICJ, MH17, State responsibility, Ukraine.

\section{INTRODUCTION}

The paper seeks to identify the means in which the key principles of the international rule of law are applied in practice. It postulates that the development of the international rule of law is fostered by the plurality of legal remedies that can be invoked upon a single event. Thus, the paper evaluates the ongoing and potential legal proceedings against States in relation to the downing of flight MH17. It provides an outline of the case-relevant provisions entrenched in the international law of treaties, international human rights law and law governing civil aviation. The paper will primarily focus on the

* The author is a student of the LLM programme at the Geneva Academy of International Humanitarian Law and Human Rights, mina.radoncic@geneva-academy.ch. 
judicial means of dispute settlement in international law and connect them to the basic principles of State responsibility enshrined in public international law.

After making preliminary theoretical remarks on the notion of the international rule of law, this paper goes on to examine its existence in practice through the prism of a single event - the downing of MH17. On 17 July 2014, the crash of Malaysia Airlines Flight MH17 on the territory of the Donetsk Oblast in Eastern Ukraine caused the death of 298 people. The airplane was routed from Amsterdam to Kuala Lumpur, and the majority of victims were nationals of the Netherlands, followed by Malaysia and Australia. The incident was followed by Dutch-led investigation into the cause of the crash conducted in a complex environment, and alongside difficulties of obtaining evidence stemming from the ongoing armed conflict in Eastern Ukraine.

The plethora of ongoing legal proceedings caused overlaps in the international arena on the issue of the downing of MH17 - one catastrophic incident wrapped around a greater politically charged issue of the relations between Ukraine and Russia. While scholars (see Hill-Cawthorne 2019, 779-815) have written on the modalities of positions taken up by international courts on adjudicating on portions of greater issues, this paper seeks to do the reverse. With the exception of the pertinent individual applications and the Dutch inter-State application (in which it is also stated that it shows support to the individual proceedings), the three international bodies are currently tackling the dispute from a perspective wider than the MH17 incident - namely, upon analysis of the situation in Eastern Ukraine (as well as Crimea), with each of them grasping the question of redress for the downing of MH17. The objective of this paper is to showcase the different efforts to bring justice and the particular modalities of ramifying the MH17 case within them.

The focus of the paper is chiefly on the ongoing proceedings seeking State responsibility - namely, the International Court of Justice (ICJ) and the European Court of Human Rights (ECtHR). Starting with the ICJ, it will assess the conclusions of the Judgment delivered in the case of Ukraine v. Russian Federation, in relation to the provisions of the International Convention for the Suppression of the Financing of Terrorism (ICSFT). The paper will tackle the issues concerning the 
interpretation of treaty norms and jurisdiction ratione materiae of the Court, seeing these questions were brought up by the parties during the proceedings (ICJ, Ukraine $v$ Russian Federation, 2019) ${ }^{1}$.

Turning to the human rights realm, the paper will shift to another forum - the ECtHR. It will provide an overview of the current proceedings - namely, the recently lodged inter-State application of the Netherlands against the Russian Federation, on account of providing the BUK missile used to shoot down the airplane and thus being responsible for violations of the right to life, prohibition of torture and inhuman or degrading treatment, and the right to an effective remedy - human rights enshrined in the articles of the European Convention of Human Rights (ECHR) (ECHR, 2020). Likewise, it will consider the individual proceedings lodged against Ukraine and Russia on similar accounts before the ECtHR ${ }^{2}$.

Before its final observations, the paper will turn to the ongoing criminal procedures in the Netherlands and provide a cursory overview of the preliminary investigation by the Office of the Prosecutor of the International Criminal Court (OTP ICC). Thereupon, it will assess their interplay with the ongoing proceedings against States as part and parcel of the efforts to uphold the international rule of law, particularly in light of the question of attributability of acts of the separatist forces to Russia.

\section{THE INTERNATIONAL RULE OF LAW}

\subsection{Preliminary Remarks}

The rule of law is perceived as a political ideal of governing modern societies. The concept is premised on three key elements - regulation of State power by law (government of laws), independence of the judiciary that regulates the application of law to the sovereign (supremacy of the law), and equality of all persons before the law (equality before the law). Albeit "thin", such a formalistic view on the rule of

${ }^{1}$ ICJ, Application of the International Convention for the Suppression of the Financing of Terrorism and of the International Convention on the Elimination of All Forms of Racial Discrimination (Ukraine v. Russian Federation), (Judgment), 8 November 2019.

2 ECtHR, Ioppa and Others v. Ukraine [2016], Application No. 73776/14 (ECtHR). ECtHR, Ayley and Others v. Russia [2016], Application No. 25714/16 (ECtHR). ECtHR, Angline and Others v. Russia [2018], Application No. 56328/18 (ECtHR). 
law has been upheld in international fora, where it is understood as the cornerstone of human rights protection, economic development, and peace and security, as underlined by Simon Chestermann $(2007, \$ 15)$.

The domestic rule of law notion was transposed by analogy to the international arena, seeking to bridge the gaps between the two, especially in lack of a centralised system of international law-making, according to Bhupinder S. Chimni $(2012,292-293)^{3}$. Taking into account the idiosyncrasies of the international order, particularly the lack of vertical integration and structural hierarchy, James Crawford adapts the definition into five core elements: formal equality of States, democracy and accountability, legal constraints imposed on authorities, international constitutionalization, and the availability of remedies to social injustice (2013a, \$441). Analogous to an international constitution, Chestermann shows that the UN Charter incorporates the rule of law in its preamble and sets foot on the duty of States to peaceful means of dispute settlement, including judicial remedies $(2007$, \$39). Furthermore, the United Nations General Assembly (UNGA) Resolution 67/1 (2012) goes on to acknowledge the contribution of international courts and tribunals, alongside the ICJ, the "centre of gravity" of a non-hierarchically organised international system, to the advancement of the rule of law at international and national levels ${ }^{4}$.

Notwithstanding, concerns were recently raised in the international arena over the emergence of a fragmented international law, as Elena Katselli Proukaki shows $(2010,241)^{5}$. Pertinent matters were tackled at the International Law Commission, with the specially designated Study Group led by Martti Koskenniemi. The contemporary proliferation of international courts and tribunals and their competing jurisdiction, coupled with a growing number of its decisions, raised

3 "What distinguishes the international rule of law from its internal counterpart is the decentralised character of international society. In the absence of a world State, international law is not made by an elected world legislature but by the principal subjects of the law, States themselves." See Chimni. 2012, 292-293.

4 UNGA Resolution 67/1, Declaration of the High-level Meeting of the General Assembly on the rule of law at the national and international levels, A/RES/67/1, 30 November 2012. https://www.un.org/ruleoflaw/files/A-RES-67-1.pdf (last visited 24 August 2020).

5 "In the absence of a clear separation of powers in the international legal order, international law comprises several autonomous legal regimes and norms that, as discussed already, may at times clash between them, endangering the integrity of international law." See Katselli Proukaki. 2010, 241. 
issues on international law "growing without any overall plan", as highlighted by Crawford (2013a, 284 fn. 698).

On the other end of the spectrum were authors such as Christopher Greenwood who, although acknowledging that the debate could not be overlooked, rather denominated it as diversity, and thus a positive, strengthening trait of international system $(2015,55)$. Ultimately, Greenwood argues that, as it is now, the international system gives an opportunity to States with common will to reach agreement more easily, shaped in arrangements among coalitions. As long as there is a centre of gravity and sufficient mechanisms to resolve its inherent inconsistencies, diversity does not imperil unity $(2015,39-40)$.

\subsection{ICJ and ECtHR: Fragmentation or Integration?}

Corroborating the complementary nature of unity and diversity in international law, Dean Spielmann underlines the interaction between the ICJ and the ECtHR and due regard for the jurisprudential links between them $(2015,179-181)$. Spielmann mentions that the high consistency between the work of the two courts was highlighted by Dame Rosalyn Higgins as well, maintaining the importance of dialogue in order to inhibit the threats posed by a disintegrated system $(2015,189-190)$. On a similar note, Magdalena Forowicz attests to a greater convergence between the courts, only to defend that the ECtHR's departures from ICJ in cases were dictated so by the exigencies of the ECHR's nature as a human rights instrument $(2015,207)$.

Spielmann adds that the ECtHR took due regard of the ICJ's findings particularly in politically charged contexts (2015, 175-176). Ultimately, he identifies the fields in which the ECtHR directly invoked ICJ jurisprudence, listing, inter alia, procedural questions, extraterritoriality, treaty interpretation ${ }^{6}$, reparations, as well as the cross-references in the realm of State immunities (2015, 177-187). Likewise, but one example of the courts' convergence lays is the "effective control" test. As explained by Iulia Motoc and Johann Justus Vasel in their comment on the Chiragov case, the ECtHR mirrored the ICJ's assessment of the relationship between a State and a non-State actor in Nicaragua so as to assert the extraterritorial establishment of jurisdiction due to indirect effective control over an area (2018, 207-210).

6 For a comprehensive overview of the reception of VCLT rules at the ECtHR, see Crawford, Keene 2020, 938-940. 
A question remaining particularly relevant for the case discussed in the present article is the courts' interaction with regards to State responsibility for discharging positive obligations. As revisited by Crawford and Amelia Keene, a discrepancy in the courts' approach was spotted with regards to positive obligations of States, with the ECtHR going farther than the ICJ $(2019,946-947)$. Rosana Garciandia shows that the ECtHR thus departed from the ILC Articles on The Responsibility of States for Internationally Wrongful Acts (ARSIWA), chiefly insofar as it circumvented the ICJ's reliance on Article 8 ARSIWA for attribution and instead strived towards establishing State responsibility for not discharging its obligation to prevent rights' violations. Further, with regards to States' complicity via aid or assistance in internationally wrongful acts, the ECtHR expanded Article 16 ARSIWA so as to include "acquiescence or connivance" more broadly (2020, 180-184).

These discrepancies raised discussions on the relationship between general international law and the ECHR as a "self-contained regime". The ICJ's referral to the findings of the Human Rights Committee in Diallo, coupled with the ECtHR's findings in Catan, formed the basis of the complementarity principle asserted by Motoc and Vasel. Namely, through its implicit employment of the lex specialis principle, the ECtHR could maintain the ground notion of responsibility in general international law, whilst developing it through its particular benchmarks for establishing jurisdiction. Hence, the ECtHR vouches for harmony instead of fragmentation $(2018,202-205)$.

Accounting for both possible ambiguities and difficulties in appropriately applying ARSIWA in practice, the ICJ holds a key opportunity in shedding light on the question of States' positive obligations through its jurisprudence, including the Ukraine v. Russian Federation case. Garciandia asserts the ICJ will thereby foster judicial integration between the two courts and their consistency in matters of general international law $(2020,184-187)$.

\section{DOWNING OF MH17 - FACTUAL BACKGROUND AND INVOKED PROCEEDINGS}

Following the anti-government protests which sparked in February 2014, Eastern Ukraine witnessed a rapid increase in the intensity of hostilities. After having held a referendum on 11 May 2014, the 
Donetsk and Luhansk People's Republics (DPR and LPR) made selfdeclarations of independence from Ukraine and held control over the respective territories in June and July ${ }^{7}$. July 2014 was accompanied with intense armed clashes between the armed forces of Ukraine and the separatist forces ${ }^{8}$.

In accordance with conventions governing civil aviation, Ukraine closed its airspace up to level 320 (height of 32,000 feet) as reported by $B B C$ (2014), whereas The Guardian mentioned that a number of airplane companies cancelled their flights with the planned route over the territory of eastern Ukraine (2014). Flying at the height of 33,000 feet, on 17 July 2014, at 15:20 CET, a Malaysia Airlines Boeing 777-200 registered under 9M-MRD was flying from Amsterdam Schiphol Airport on its way to Kuala Lumpur, Malaysia. There was 283 passengers and 15 crew members on board. The airplane was hit whilst flying over the territory of eastern Ukraine and it disintegrated in the airspace, with all 298 persons losing their lives. ${ }^{9}$ As a response to the incident, the United Nations Security Council (UNSC) unanimously adopted Resolution 2166 on 21 July 2014, in support of international cooperation on conducting investigations into the incident and seeking accountability, along with demanding that the relevant actors grant access to the crash site ${ }^{10}$.

Following its domestic efforts, Ukraine concluded an agreement with the Dutch authorities on 23 July 2014 delegating to it the investigation. Thereon, the Dutch Safety Board (OVV) was the main body conducting the investigation alongside the participation of other countries $^{11}$. operating in conformity with Annex 13 of the Convention on

7 ICC, 2018. Report on Preliminary Examination Activities. $\$ \$ 69-73$. https:// www.icc-cpi.int/itemsDocuments/181205-rep-otp-PE-ENG.pdf (last visited 07 November 2020).

8 ECtHR, Ayley and Others v. Russia [2016], Application No. 25714/16 (ECtHR). ECtHR, Angline and Others v. Russia [2018], Application No. 56328/18 (ECtHR), Statement of Facts and Questions, $\$ \$ 7-8$.

${ }^{9}$ ECtHR, Ioppa and Others v. Ukraine [2016], Application No. 73776/14 (ECtHR), Statement of Facts and Questions.

10 UNSC Resolution 2166, 21 July 2014. https://digitallibrary.un.org/ record/775348?ln=en\#record-files-collapse-header (last visited 13 February 2021).

11 Principally the participation of Ukraine, Malaysia, United States of America, United Kingdom, and with Australia and the Russian Federation apportioning requested information. See ECtHR, Ayley and Others v. Russia [2016], Application No. 25714/16 (ECtHR). ECtHR, Angline and Others v. Russia [2018], Application No. 56328/18 (ECtHR), Statement of Facts and Questions, $\$ 17$. 
International Civil Aviation (1944 Chicago Convention), which tackles investigating aircraft accidents and incidents. With the first ground visit being conducted in November 2014, the final report was published in October 2015, concluding that the warhead by which the airplane had been struck was launched from a BUK surface-to-air missile system ${ }^{12}$.

With the OVV investigation running in parallel, Australia, Belgium, Malaysia, the Netherlands and Ukraine established a Joint Investigation Team (JIT) in August 2014. Whereas the OVV had the objective of establishing the causes of the crash and contributing factors, the JIT criminal investigation had a different focus, also seeking accountability and collection of evidence to be used in judicial proceedings. Whereas its findings in 2016 concluded that the BUK missile was fired from the area of Pervomaiskyi, at the time controlled by the separatist groups, the 2018 report pinpointed the 53rd Anti-Aircraft Missile Brigade from Kursk in Russia as the origin of the BUK TELAR that caused the downing of MH17. The JIT also condemned Russia's lack of cooperation during the proceedings. Russia refuted allegations on being involved in the incident, also denouncing the investigation to be based on the presumption of Russia's responsibility and biased.

The incidents provoked an outburst of debate over possible legal avenues for seeking accountability for the incident (see particularly: Milanović 2014; Matta 2015a; De Hoon, Fraser, McGonigle Leyh 2016; De Hoon 2017). The governments of the Netherlands and Australia claimed Russia's responsibility for the incident in May 2018 and called on the country to engage in discussions and open dialogue, as reported by The Guardian (2018). Additionally, several claims were made on the possible responsibility of Ukraine, on accounts of not completely closing the airspace over the conflict zone. Ultimately, some accounts were directed at Malaysia Airlines, for not cancelling the flight in light of the avoidance policy of other companies.

In the meantime, efforts by the JIT Member States at the UNSC on adopting a resolution establishing an international tribunal on the MH17 crash were rendered futile as a result of Russia's veto in July 2015. As reported from the UNSC meeting, the delegate of the Russian Federation upheld the call for the establishment of a "truly independent" international investigation, and reminded that the UNSC Resolution 2166 (2014) did not deem the incident a threat to international peace and security (2015).

12 Ibid., para. 25. 
Thus, with international consensus on looking into the incident not being reached, several proposals were made on how to address the situation in Ukraine from the standpoint of international law, both from the perspective of criminal responsibility against individuals and State responsibility. In the State responsibility realm, scholars such as Marieke de Hoon focused on civil aviation conventions, considering different alternatives: proceedings before the ICJ on the basis of civil aviation conventions, the establishment of dispute settlement mechanisms in the forms of fact-finding and inquiry commissions, or arbitration (2017, 99-101).

What happened in practice is that Ukraine submitted an Application to the ICJ, claiming the Russian Federation to be in breach of its obligations of the International Convention for the Suppression of the Financing of Terrorism (ICSFT) and the International Convention on the Elimination of All Forms of Racial Discrimination (CERD) in January 2017. In addition to that, the ECtHR was deemed another forum at which multiple proceedings were raised against Russia. While the situation in Eastern Ukraine in general was brought to the ECtHR by Ukraine, the recent Dutch application concerns the downing of MH17 specifically. ${ }^{13} D W$ reported that such a move from the Netherlands sparked a reaction from Russia who consequently decided to withdraw from the trilateral talks with the Netherlands and Australia, accusing them of "hostile acts" aiming to "assign responsibility to Russia" (2020). The inter-State proceedings are coupled with a multiplicity of individual complaints, both against Ukraine and Russia ${ }^{14}$.

\section{INTERNATIONAL COURT OF JUSTICE}

\subsection{Preliminary Remarks: Why Not Seek Responsibility for the Downing of MH17 Directly?}

At the time of the MH17 incident, questions were raised on the possibility of bringing a case directly to the Court. To summarise what

13 ECtHR. 2020. New inter-State application brought by the Netherlands against Russia concerning downing of Malaysia Airlines fight MH17. Press Release, ECHR 213 (2020).

14 ECtHR, Ioppa and Others v. Ukraine [2016], Application No. 73776/14 (ECtHR). ECtHR, Ayley and Others v. Russia [2016], Application No. 25714/16 (ECtHR). ECtHR, Angline and Others v. Russia [2018], Application No. 56328/18 (ECtHR). 
was argued by Aaron Matta, such a scenario could have hypothetically played out both against Ukraine and Russia, for different aspects. In the case of Ukraine, the question to have plausibly been raised was one of harm caused by omission, à la Corfu Channel, if not direct responsibility for firing the missile (2015a). In the Corfu Channel case, Albania was deemed responsible for failing to notify the United Kingdom of mines laid in its territorial waters, which eventually caused damage to the British ships, in spite of a third State laying them in the first place. Secondly, in light of the inconclusive information concerning the involvement of Russia in the incident and its exact relation with the separatist groups, a scenario parallel to the Nicaragua case could have been envisaged, mirroring the Court's assessment of the US' degree of control exercised over the contras. Commenting on the plausibility of such claims being brought against Russia, Mark Gibney argues that, in light of general hesitation of the Court to establish State responsibility when involved in activities outside its borders, the most probable scenario would be proving that Russia provided aid and assistance (2015, 169-178). However, the likelihood of such proceedings being instituted was very low, chiefly considering that the jurisdiction of the Court is premised on States' consent.

Additionally, the option of requesting the Court's Advisory Opinion through the UNGA or the International Civil Aviation Organization (ICAO) was revisited, as a way to shed light on the case's legal considerations (see De Hoon 2017, 101). Such a scenario was corroborated by States' support for the UNGA's resolution in March 2014 concerning the respect of Ukraine's territorial integrity. However, its value was deemed tainted by its non-binding nature and the Court's avoidance of politically charged issues, as Isabella Risini shows (2018, 158). Such considerations ultimately led to Ukraine framing its claims against Russia as ICSFT and CERD violations.

\subsection{Proceedings currently raised at the Court}

On the basis of alleged violations of the ICSFT and CERD by the Russian Federation, Ukraine filed an Application in January 2017, instituting proceedings at the $\mathrm{ICJ}^{15}$. Whereas violations of the CERD

15 ICJ, Application of the International Convention for the Suppression of the Financing of Terrorism and of the International Convention on the Elimination of All Forms of Racial Discrimination (Ukraine v. Russian Federation), (Application instituting Proceedings), 16 January 2017, \$\$124-130, \$\$135-136. https://www.icj-cij.org/ 
were referring to the situation in Crimea, allegations on the basis of the ICSFT concerned eastern Ukraine and included Ukraine's claim that Russia bears international responsibility and that it has to pay compensation to the victims of the MH17 incident. In its submissions, Russia urged the Court to declare it lacked jurisdiction on the matter and/or pronounce the case inadmissible ${ }^{16}$.

\subsubsection{Application}

In its Application to the Court, Ukraine sought to bring the activities in eastern Ukraine within the realm of the ICSFT. Thereby, it characterised the recurring events as terrorist acts, coupling them with the claim that such acts occurred as a result of Russia's failure to comply with the ICSFT. Ukraine maintained the scope spelled out in Article $2 \$ 1$ ICSFT, stating that "[a]ny person commits an offence within the meaning of this Convention if that person, by any means, directly or indirectly, unlawfully and wilfully, provides or collects funds with the intention that they should be used or in the knowledge that they are to be used, in full or in part, in order to carry out [the following] acts" (emphasis added) ${ }^{17}$. In the case of the downing of MH17, Ukraine relied on Article 2\$1a) ICSFT, specifying that the scope of the Convention would cover offences of the treaties listed in its annex, where the Convention for the Suppression of Unlawful Acts against the Safety of Civil Aviation (1971 Montreal Convention) is included ${ }^{18}$. Moreover, Article 1\$1b) 1971 Montreal Convention states that "[a]ny person commits an offence if he unlawfully and intentionally destroys

public/files/case-related/166/166-20170116-APP-01-00-EN.pdf (last visited 25 November 2020).

16 Report of the International Court of Justice 2018/19, United Nations, General Assembly, Official Records, Seventy-fourth Session, Supplement No. 4; New York, 2019, \$190. https://www.icj-cij.org/public/files/annual-reports/2018-2019-en.pdf (last visited 25 November 2020).

17 International Convention for the Suppression of the Financing of Terrorism, Article $2 \S 1$.

18 The application of the ICSFT sparked debates over its concurrent application with the norms of international humanitarian law, particularly in light of the provision of Art. 2\$1b) ICSFT. Namely, Trapp highlights the explicit interplay between the norms of ICSFT and IHL, where the provisions of Article 21 ICSFT infer to IHL as lex specialis. She brings to the fore the obligations of Article 3 Common to the 1949 Geneva Conventions and the ICRC's interpretation of Common Article 1 as a negative obligation of States to "refrain from encouraging, aiding or assisting in violations of the Conventions by Parties to the conflict", coupled with Article $2 \$ 1 \mathrm{~b}$ ) of the ICSFT. For a more comprehensive overview, see Trapp. 2017. 
an aircraft in service or causes damage to such an aircraft which enders it incapable of flight or which is likely to endanger its safety in flight" (emphasis added) ${ }^{19}$.

Ukraine therefore maintained that acts of terrorism occurred as a consequence of Russia's breach of its obligations under the ICSFT, namely:

- Article 8, by failing to take appropriate measures to supress that funds be allocated to activities listed in Article 2,

- Articles 9 and 10, on account of not taking appropriate measures of investigation into and prosecution of the alleged perpetrators of those offences,

- Article 12, by not providing appropriate assistance to other States in the criminal investigations of the alleged perpetrators,

- Article 18, on account of not cooperating on the efforts to prevent and supress acts of terrorism ${ }^{20}$.

Finally, Ukraine relied on Article 24 ICSFT as a basis for the ICJ's jurisdiction, seeing that both Ukraine and Russia are parties to the Convention. Article 24 allows for a dispute concerning the Convention's interpretation and application to be brought before the Court, provided that certain steps be previously satisfied (i.e., negotiations within reasonable time, followed by a six-months lapse of the request for arbitration $)^{21}$.

\subsubsection{The Court's assessment on provisional measures}

Subsequent to Ukraine's request, the Court issued provisional measures in the case in April 2017, however only tackling the questions re the situation in Crimea and adding a more "general" measure, that the parties abstain from any action which would further the dis-

19 Convention for the Suppression of Unlawful Acts against the Safety of Civil Aviation (1971 Montreal Convention), Article 1\$1b).

20 Article 11 ICSFT was also originally included in the Application of Ukraine but left out in the Memorial on merits. See ICJ, Application of the International Convention for the Suppression of the Financing of Terrorism and of the International Convention on the Elimination of All Forms of Racial Discrimination (Ukraine v. Russian Federation), (Judgment), 8 November 2019.

21 International Convention for the Suppression of the Financing of Terrorism, Article 24. 
pute, as Iryna Marchuk explains (2019) ${ }^{22}$. The rejection of the Court to issue provisional measures in relation to the ICSFT provoked more reactions on both sides of the spectrum. Concerns were raised on substantial grounds in general, as well as procedural grounds pertinent to the provisional measures themselves.

As Anne Peters highlights, upon deciding to issue provisional measures, the ICJ assesses three conditions that must be satisfied:

1. "prima facie existence of jurisdiction,

2. the plausibility of rights for which protection is sought,

3. risk of irreparable prejudice and urgency (2017)."

The analysis of a prima facie existence of jurisdiction entailed issues on both procedural and substantive grounds. When concerned with procedural questions in the section of prima facie jurisdiction, the Court analysed whether other remedies were previously exhausted before referring the dispute to the Court, as required by Article 24 ICSFT. In spite of Russia's counterclaims, the Court declared that, with two years having passed since the beginning of negotiations, the "reasonable time" requirement was fulfilled. Furthermore, it found that the efforts to settle the dispute by way of arbitration saw little progress. An interesting issue was (almost) raised, with Russia arguing that there was no genuine attempt by Ukraine to settle the dispute by arbitration, aiming principally to bring the dispute to the Court. It underlined Ukraine's proposal that an ad hoc chamber of the Court be established, in substitute to arbitration. Ukraine contended this argument, saying the proposal was only made as an alternative solution to arbitration. Ukraine's stance was eventually backed up by the Court. ${ }^{23}$

Discussing thereupon the substantive issues in relation to its jurisdiction prima facie and the plausibility of rights to be protected, the

22 By analogy with the case of Georgia v. Russia on accounts of violations of CERD in 2008, it was deemed that Ukraine managed to avoid Georgia's path of reasoning, which ultimately resulted in the Court dismissing the charges on jurisdictional grounds. See Marchuk. 2019.

23 ICJ, Application of the International Convention for the Suppression of the Financing of Terrorism and of the International Convention on the Elimination of All Forms of Racial Discrimination (Ukraine v. Russian Federation), (Request for the Indication of Provisional Measures), 19 April 2017. https://www.icj-cij.org/public/files/ case-related/166/166-20170419-ORD-01-00-EN.pdf (last visited 09 November 2020). For the argumentation of Ukraine, see $\$ \$ 47-48$; for the argumentation of Russia, see $\$ \$ 49-51$; for the conclusion of the Court, see $\$ 54$. 
Court first determined whether there was a dispute between the parties related to the Convention. For its part, Ukraine maintained that Russia provided support to the separatists knowing that they would be used in acts of terrorism, thus amounting to a breach Article 2 ICSFT. It added that, by failing to cooperate in preventing terrorism financing, Russia violated Article 18 ICSFT. Ukraine invoked the argument on the basis of Article 18 in the latter section of the plausibility of rights as well ${ }^{24}$.

Russia challenged the argumentation of Ukraine on three accounts. Firstly, it stated that Ukraine was attempting to frame the ongoing unrest as acts of terrorism, which was not supported by the international community ${ }^{25}$. It corroborated its findings in the subsequent section on the plausibility of rights whose protection is sought, maintaining that the paradigm of international humanitarian law was more appropriate to cover the hostile acts, with the listed incidents falling outside the scope of the ICSFT ${ }^{26}$. Thereon, Russia contended the scope of application of the ICSFT, maintaining that it was only meant to be directed at the behaviour of private actors and not State activity directly ${ }^{27}$. It invoked similar grounds for denying the obligation to cooperate in investigations in the latter section on the plausibility of rights. Finally, Russia moved on to disprove the existence of the intent and knowledge of how the funds provided would be employed ${ }^{28}$.

Concluding that a dispute between the parties existed for at least one part of the provisions, the Court assumed it had prima facie jurisdiction in the present case. ${ }^{29}$ Nonetheless, moving to the second substantive issue, the Court based its assessment on whether the evidence suggested that the elements of intention or knowledge (pursuant to Article $2 \$ 1$ ICSFT) as well as purpose (pursuant to Article $2 \$ 1(\mathrm{~b}$ ) ICSFT) could be inferred. On the basis of not having enough evidence to conclude so, the Court determined that the condition was not met and rejected to issue provisional measures on account of possible violations of ICSFT.

The Court therefore did not enter into analysing the risk of irreparable prejudice and urgency with regards to the ICSFT, pro-

24 Ibid., paras. 24-25, 66, 68.

25 Ibid., para. 26.

26 Ibid., paras. 69-70.

27 Ibid., para. 27.

28 Ibid., para. 26.

29 Ibid., para. 31. 
nouncing itself only on the second limb of the dispute (i.e., the alleged CERD violations) ${ }^{30}$. The Court's conclusion was criticised on various grounds. Dimitris Kontogiannis argued that the ICJ blurred the line between incidental proceedings and deciding on the merits. By introducing a shift from the test of legal plausibility of rights into the one of factual plausibility of claims, it turned the stage of provisional measures into a mini-trial (2019) ${ }^{31}$. Judge Antônio A. Cançado Trindade argued for a different test to be adopted instead - namely, that of "vulnerability of rights", suggesting a turn to a human rights perspective of the claims and downplaying the inter-State character of the dispute. ${ }^{32}$ In response to its proposal, Petters adopted a middle approach, suggesting the plausibility of the provisions' violations towards Ukraine, alongside the vulnerability of the victims of international terrorism as the threshold (2017).

\subsubsection{Judgment}

The Court confirmed it had jurisdiction on the matters of the ICSFT in its Judgment delivered on 8 November 2019. With regards to issues of substance, it thereupon addressed some of the questions left at the stage of incidental proceedings. Firstly, it tackled the issue of pronouncing on the facts at the stage of establishing jurisdiction. In light of its argument that the dispute fell out of the framework of ICSFT, Russia contended that the Court should take into account the factual circumstances before establishing jurisdiction. ${ }^{33}$ Ukraine argued that such an approach would erase the difference between the current

30 Ibid., paras. 87, 99, 106.

31 "What is required, is reasonable possibility that the right exists in abstracto as matter of law, and not proof nor probability of success on merits. [...] The Court aims at protecting rights (and their exercise) from being irreparably harmed" (emphasis added). See Kontogiannis 2019.

32 ICJ, Application of the International Convention for the Suppression of the Financing of Terrorism and of the International Convention on the Elimination of All Forms of Racial Discrimination (Ukraine v. Russian Federation), (Request for the Indication of Provisional Measures), Separate Opinion of Judge Cançado Trindade, 19 April 2017, \$\$36-41. https://www.icj-cij.org/public/files/case-related/166/16620170419-ORD-01-03-EN.pdf (last visited 9 November 2020).

33 ICJ, Application of the International Convention for the Suppression of the Financing of Terrorism and of the International Convention on the Elimination of All Forms of Racial Discrimination (Ukraine v. Russian Federation), (Judgment), 8 November 2019, \$40. https://www.icj-cij.org/public/files/case-related/166/166-20191108JUD-01-00-EN.pdf (last visited 12 November 2020). 
stage and the pronouncement on merits ${ }^{34}$. The Court concluded by saying it needed to consider relevant questions of law and fact in order to establish jurisdiction ${ }^{35}$.

Furthermore, the Court shed some light on the issue of State financing of terrorism. Similar to the provisional measures stage, the Russian Federation claimed that the Convention was not intended to regulate the conduct of State officials and provided only State obligations vis-à-vis private individuals. It thereupon relied on the textual interpretation of the Convention, corroborated by the travaux préparatoires testifying the attempts of States to exclude questions of State responsibility resulting from the Convention ${ }^{36}$. To the contrary, Ukraine claimed that the wording of Article 2 did not suggest any limits as to which persons it referred, thus being equally applicable to public officials. Similar to the arguments of the Court in the Genocide case $^{37}$, it claimed that an interpretation which would oblige States to prevent and suppress the financing of terrorism by others but leave open the possibility for the State itself to commit such activities would lead to absurd results, defying the object and purpose of the Convention (see also Proulx 2017) 38 . Upon addressing this question, the Court concluded that the conduct of State officials was not prohibited ipso facto by Article 2, but that breaches of ICSFT obligations by States undoubtedly incurred State responsibility, such as by failing to "take appropriate measures and cooperate in the prevention and suppression of offences of financing acts of terrorism committed by whichever person" 39 . Notwithstanding, the Court invoked the UNSC Resolution 1373 (2001) that called upon States to not support terrorist acts by any means ${ }^{40}$.

34 Ibid., paras. 47, 51.

35 Ibid., para. 58.

36 Ibid., paras. 43-44.

37 ICJ, Case Concerning Application of the Convention on the Prevention and Punishment of the Crime of Genocide (Bosnia and Herzegovina v. Serbia and Montenegro), (Judgment), 26 February 2007, \$166. https://www.icj-cij.org/public/files/caserelated/91/091-20070226-JUD-01-00-EN.pdf (last visited 13 November 2020).

38 ICJ, Application of the International Convention for the Suppression of the Financing of Terrorism and of the International Convention on the Elimination of All Forms of Racial Discrimination (Ukraine v. Russian Federation), (Judgment), 8 November 2019, \$53. https://www.icj-cij.org/public/files/case-related/166/166-20191108JUD-01-00-EN.pdf (last visited 12 November 2020).

39 Ibid., paras. 9, 61.

40 Ibid., para. 60. 
Moreover, the question of the required mental element arose. The Russian Federation invoked several arguments on account of the necessary intent and knowledge enshrined in Article 2\$1 ICSFT. Firstly, it claimed that no evidence inferred Russia's knowledge of using the weapons to shoot down MH17. Then, Russia maintained that the threshold of knowledge precluded mere recklessness and required that there actually be knowledge of the means of employing the provided funds. Finally, it read the 1971 Montreal Convention so as to require an additional mental element - namely, that of subjective aim to "destroy or cause damage to a civilian aircraft in service" 41 . Ukraine opposed Russia's arguments by invoking the ordinary conduct of the separatist groups to satisfy the threshold of knowledge. Moreover, it refuted the interpretation of mens rea in the Montreal Convention, arguing that it merely referred to the "ordinary consequences of an act" 42 . Leaving this issue for the possible merits stage, the Court concluded it did not need to pronounce on the issue of the required intention and knowledge at this moment ${ }^{43}$. In its Application, Ukraine invoked the ongoing armed conflict to be the contextual element from which the mental element of intent in a terrorist act could be inferred. Thereupon, scholars drew parallels with ICTY's jurisprudence (see Trapp 2017).

Ukraine's argument on the presence of intent was deemed as the weakest point of the claim by Marchuk, due to it generally being difficult to prove and exacerbated by the bleak factual circumstances of the case (2019). On that note, Vincent-Joel Proulx saw the proceedings at the ICJ as an opportunity to gain more clarity on the meaning of contested provisions of the ICSFT. He argued that the ICSFT should witness an evolutionary interpretation of the requisite mental element, especially after the 9/11 attack. He suggests upholding more exigent due diligence obligations by States in preventing terrorism (2017).

Additionally, albeit not contested by the Respondent, the Court confirmed Ukraine's reading of the Convention re the covered scope of funds, so as to include supplying weapons ${ }^{44}$. Finally, the Court

41 Ibid., paras. 42, 45-46.

42 Ibid., paras. 50, 54.

43 Ibid., para. 63.

44 ICJ, Application of the International Convention for the Suppression of the Financing of Terrorism and of the International Convention on the Elimination of All Forms of Racial Discrimination (Ukraine v. Russian Federation), (Judgment) 8 November 2019, $\$ \$ 52,62$. https://www.icj-cij.org/public/files/case-related/166/16620191108-JUD-01-00-EN.pdf (last visited 12 November 2020). 
confirmed its findings on the procedural grounds for establishing the Court's jurisdiction according to Article 24 ICSFT $^{45}$.

By way of its Order on 20 January 2021, the Court extended the time-limit for filing the Counter-Memorial by Russia to 8 July 2021, in light of the COVID-19 pandemic ${ }^{46}$.

\section{EUROPEAN COURT OF HUMAN RIGHTS}

\subsection{Individual Applications against Ukraine and Russia}

With over 4,000 individual pending applications concerning the situation in eastern Ukraine and six inter-State applications more broadly, the ECtHR has been deemed the staple of the process and Ukraine's multi-forum litigation strategy against Russia (see particularly Ulfstein, Risini, 2020). Among the applications lodged against Russia by the relatives of the victims of the MH17 incident are Ayley and Others v. Russia (application no. 25714/16) and Angline and Others v. Russia (application no. 56328/18). The applicants are 380 individuals of 14 nationalities, claiming Russia to be accountable either directly or indirectly for the crash, for not itself investigating and not cooperating with the investigations. Relying on the findings of the investigation teams, the applicants in Angline and Others v. Russia offer the Court four scenarios of Russia's involvement in the event, namely:

1. Russia participated in deciding to launch the missile at the airplane,

2. Russia's military presence on the ground could have prevented the firing but did not do so,

3. Russia provided the BUK TELAR and missile to the separatist groups and had not monitored its use, thus being complicit in the attack,

45 Ibid., paras. 70, 76.

46 ICJ, Application of the International Convention for the Suppression of the Financing of Terrorism and of the International Convention on the Elimination of All Forms of Racial Discrimination (Ukraine v. Russian Federation), (Order), 20 January 2021. https://www.icj-cij.org/public/files/case-related/166/166-20210120-ORD-01-00EN.pdf (last visited 11 February, 2021). 
4. Russia did not keep control over the BUK TELAR, making it possible for the separatists to use it ${ }^{47}$.

The applicants thus invoke a breach of Article 2 ECHR concerning the right to life both in substantive terms as well as Russia's procedural obligation of investigating, as Marko Milanović explains (2019).

Additionally, the Court examines the applicants' claim that the violation of the procedural obligation to investigate amounted to ill-treatment caused to the victims' relatives pursuant to Article 3 ECHR, as well as a breach of Article 13 ECHR with regards to their right to an effective remedy. The Court communicated the case to Russia in April 2019 ${ }^{48}$.

On a similar note, the four applicants in Ioppa v. Ukraine maintain that Ukraine should bear responsibility for intentionally leaving the airspace above the conflict zone open at the level 330 (height of 33,000 feet) and thus violating the right to life, pursuant to Article 2 ECHR. The relatives of the deceased rely thus on the Ukraine's breaching international obligations with regards to international civil aviation, namely:

- Article 9 of the 1944 Chicago Convention, on the possibility of the State to restrict or prohibit flights due to military necessity or public safety to a reasonable extent,

- Article I of the 1944 International Air Services Transit Agreement, with regards to authorizations of flights over areas of active hostilities,

- Article $10 \$ 1$ of the 1971 Montreal Convention, on taking all feasible measures to prevent the offences listed in its Article $1 \S b$ on destroying an aircraft in service.

Thus, the argument rests on the alleged causality between the breach of an international obligation and its consequences. In its analysis on the issue of such a link, David Pusztai maintains that responsibility for harm by omission is not novel in the international arena and reminds of the Corfu Channel case as well as a similar obligation

47 ECtHR, Ayley and Others v. Russia [2016], Application No. 25714/16 (ECtHR). ECtHR, Angline and Others v. Russia [2018], Application No. 56328/18 (ECtHR).

48 ECtHR. 2019. ECHR gives notification to Russia of cases brought by relatives of people killed in the downing of Malaysian Airlines flight MH-17. Press Release, ECHR 121 (2019). 
of prevention used by the ECtHR in the Kiliç v. Turkey case (2014). However, he underlines that such an assessment rests on satisfying the "foreseeability test", namely that it should be proven that the State had or should have had knowledge of the real and immediate risk of a threat which eventually materialised. He adds that, given the particular circumstances of the case and lack of conclusive information, such a "but-for" relationship would be difficult to determine in the case of Ukraine. Finally, although not absolving it of responsibility (see Crawford 2002, 205-206; Crawford 2013b, 495-498) ${ }^{49}$, Pusztai holds that Ukraine's negligence would then possibly be concurrent to the one of Malaysia Airlines for not following the avoidance policy of other airlines (2014).

\subsection{Inter-State Proceedings by Ukraine}

Due to the need to approach the situation more comprehensively, the Court decided to adjourn a part of individual applications in December 2018, subject to the resolution of the relevant inter-State dispute concerning eastern Ukraine ${ }^{50}$. Thus, the findings of inter-State proceedings will have a crucial impact on the faith of individual applications. Notwithstanding, the compelling obstacle to the admissibility of both cases is the prerequisite, albeit not absolute, of the applicants' exhausting domestic remedies, pursuant to Art. $35 \$ 1$ ECHR $^{51}$. (see Risini, Ulfstein 2020; Matta 2015a). ${ }^{52}$

Additionally, the Court decided to reorganise the pending cases of Ukraine against Russia. The two original applications, lodged in 2014 and 2016, were divided geographically into cases concerning

49 "In the Corfu Channel case, the damage to the British ships was caused both by the action of a third State in laying the mines and the action of Albania in failing to warn of their presence. Although, in such cases, the injury in question was effectively caused by a combination of factors, only one of which is to be ascribed to the responsible State, international practice and the decisions of international tribunals do not support the reduction or attenuation of reparation for concurrent causes, except in cases of contributory fault." Crawford 2002, 205-206.

50 ECtHR. 2018. ECHR to adjourn some individual applications on Eastern Ukraine pending Grand Chamber judgment in related inter-State case. Press Release, ECHR 432 (2018).

51 ECtHR. 2020. Practical Guide on Admissibility Criteria. \$88. https://www. echr.coe.int/Documents/Admissibility_guide_ENG.pdf (last visited 12 November 2020).

52 Matta also raises the possible issue of non-compliance with the judgment by Russia in light of recent constitutional changes. See Matta. 2015a. 
Crimea, and eastern Ukraine and Donbass. Thereon, the four relevant pending cases are distinguished on account of their geographical and temporal scope, with the application Ukraine v. Russia (V) concerning events in eastern Ukraine and Donbass until September 2014 (application no. 8019/16), whilst Ukraine v. Russia (VI) is related to the situation after that date (application no. 70856/16).

The jurisdiction over the four complaints (i.e., two re Crimea and two re eastern Ukraine and Donbass) was relinquished by the Court to the Grand Chamber in 2018, pursuant to Article 30 ECHR, in light of the possible effect on the interpretation of the Convention or its Protocols, or an inconsistency with previous judgments ${ }^{53}$.

Thereupon, it will be left to the Court to discuss quintessential issues of the dispute before tackling the various proceedings. In the first place, the Court will essentially touch upon the degree of Russia's control over the separatist forces and the nature of their relationship. As Jens David Ohlin asserts, the Court's pronouncements on this aspect might entail consequences on other proceedings which would possibly be relevant in the application of norms of international humanitarian law, particularly in light of the criminal proceedings in the Netherlands and the Prosecutor's investigation at the ICC (2014).

This is also the case with the evergreen issue of extraterritorial application of human rights and scope of jurisdiction pursuant to Article 1 ECHR in the proceedings against Russia. Through its jurisprudence, the Court has clarified that the jurisdictional scope was essentially territorial, but that it could extend to places outside a State's territory in exceptional circumstances. That could be the case when a State exercised authority and control over persons (i.e., the personal model), or control over territory, regardless of the lawfulness of such action, and either directly or through the local administration, as was the situation of the Loizidou v. Turkey (1995) and Cyprus v. Turkey (2001) (i.e., the spatial model) ${ }^{54}$.

However, in light of no clear factual pattern in the present case, it was suggested that a particularly pertinent case to the issue was

53 ECtHR. 2018. Grand Chamber to examine four complaints by Ukraine against Russia over Crimea and Eastern Ukraine. Press Release, ECHR 173 (2018). Subsequently, the Grand Chamber declared Ukraine's application concerning Crimea admissible in December 2020. http://hudoc.echr.coe.int/eng?i=001-207622 (last visited 12 February 2021). For a comment, see Milanović. 2021.

54 ECtHR. 2018. Extra-territorial jurisdiction of States Parties to the European Convention on Human Rights. Fact Sheet. 1-2. 
Ilaşcu v. Moldova and Russia (2004) and the Court's more nuanced approach, insofar as Russia did not have sufficient control over the territory of Transdniestria. However, it found that continued economic, political and military support to the local separatist regime triggered Russia's obligations. ${ }^{55}$ The Court came to a similar conclusion in Chiragov and Others v. Armenia (2015), indicating Armenia's decisive military support to the Nagorno-Karabakh Republic and their degree of integration ${ }^{56}$.

Another aspect of Ilaşcu is particularly relevant - namely, the obligations of Moldova as the territorial State. The Court concluded that the jurisdictions were not mutually exclusive and that the situation on the ground incurred obligations of both States. In the case of Moldova, the Court upheld that it still had to discharge its positive obligation of taking "diplomatic, economic, judicial or other means" so as to safeguard the applicant's rights pursuant to the Convention. ${ }^{57}$ Milanović has suggested that the legacy of Ilaşcu could be transposed onto the dispute concerning MH17 (2018). Leaving aside the specificities that will come up in each case, among the issues that will have to be assessed by the Court in all instances is the possible failure of appropriately conducting investigations by Ukraine and Russia.

\subsection{Inter-State Proceedings by The Netherlands}

A new development in this process was seen in July 2020, with the Netherlands lodging an inter-State application at the ECtHR against Russia, pursuant to Article 33 ECHR. The Netherlands maintains this is a way of supporting the pending individual applications related to the downing of MH17 and standing by all 298 MH17 victims ${ }^{58}$. In its application, the Netherlands claims responsibility of Russia on account of violating Articles 2, 3 and 13 ECHR. Scholars also saw this move as

55 Ibid.

56 Ibid., 3.

57 ECtHR, Ilasçu and Others v. Moldova and Russia (Judgment), 2004. \$\$331, 352. See also ECtHR, Catan and Others v. the Republic of Moldova and Russia, 2012. ECtHR, Mozer v. the Republic of Moldova and Russia, 2016.

58 ECtHR. 2020. New inter-State application brought by the Netherlands against Russia concerning downing of Malaysia Airlines fight MH17. Press Release, ECHR 213 (2020). See also Government of the Netherlands. 2020. The Netherlands brings MH17 case against Russia before European Court of Human Rights. News Item. https://www.government.nl/latest/news/2020/07/10/the-netherlands-brings-mh17-caseagainst-russia-before-european-court-of-human-rights (last visited 12 November 2020). 
an "open invitation" to other States to bolster the erga omnes character of the Convention's guarantees by joining the proceedings, or supporting it via amici curiae (see Risini, Ulfstein 2020).

On that note, on behalf of the University of Nottingham's Human Rights Law Centre and as a third party to the proceedings, Milanović and Sangeeta Shah submitted an amicus curiae to the Court in 2021. Not discussing the disputed factual questions of the case to be determined by the Court, the authors provide a roadmap for the Court's analysis on Russia's possible link with the incident. Their submission draws attention to three essential issues - the difference between attribution and jurisdiction, relevance of mistake of fact in the incident, and the alternative establishment of culpability through complicity or failure to prevent rights' violations $(2021,1)$.

Primarily, Milanović and Shah highlight the cumulative requirement of attribution and jurisdiction in order for a Convention violation to be established. Importantly, Milanović and Shah reiterate general international law as the source of provisions establishing attribution and thus invoke the relevant ARSIWA. Thereby, they distinguish between attributing the actors (i.e., either as de iure or de facto State organs, pursuant to Article 4 ARSIWA) and the conduct (i.e., via the instruction, direction or effective control over a person, in accordance with Article 8 ARSIWA). Furthermore, they revisit the two models of establishing the notion of jurisdiction pursuant to the Court's jurisprudence under Article 1 ECHR. In that regard, Milanović and Shah claim the personal model to be more appropriate for the case at hand, whereby the establishment of jurisdiction would chiefly depend on the "exercise of physical power" and not be subject to the artificial delineation of the location of the aircraft at the moment of the incident ${ }^{59}$. Thus, the ECtHR would be more in line with the findings of other human rights bodies who establish less stringent tests for asserting jurisdiction (2021, 1-5).

Secondly, the authors assess the possibility of the incident occurring by mistake, where the intention of the perpetrators was the

59 Before suggesting greater convergence with other human rights bodies, the amicus curiae also makes a caveat with respect to the Court's case law development on personal model of jurisdiction in cases involving use of force. Namely, while noting the Court's departure from Banković in Al-Skeini and Makuchyan and Minasyan, the authors account for the Court recently retrieving its stricter interpretation in Georgia v. Russia II. See Milanović, Shah 2021, 4-5. 
destruction of a valid military target instead of a civilian object. They assert that while such a mistake of fact could, subject to conditions, preclude a rights violation, another limb must be satisfied, namely that of taking feasible precautionary measures in the preparatory phase of the operation $(2021,5-8)$.

Lastly, Milanović and Shah provide two alternatives to finding direct culpability of the State. They tie the States' duty to prevent rights violations to the concepts of jurisdiction and introduce a functional notion, namely the State's "capacity to influence the primary wrongdoer". Thereon, they make the State's responsibility dependent on the qualified knowledge about the existence of a risk of a violation occurring. Along the lines of the ICJ's approach on delineating the duty of prevention and complicity in the Genocide case (see Crawford, Keene 2019, 946) as well as the Human Rights Committee in the General Comment 36, the authors suggest the Court's further advancement of responsibility for complicity as a "middle ground" between direct perpetration and failure of prevention. They mention the ECtHR's existing threshold of "acquiescence or connivance" developed in El-Masri, although discrepancies highlighted in Section 2.2. of the paper should be borne in mind (2021, 8-10).

\section{PARALLEL CRIMINAL PROCEEDINGS}

The downing of MH17 also sparked discussions over the possibility of bringing criminal charges against the perpetrators. Suggestions included setting up a new international criminal tribunal by way of a UNSC resolution, which was vetoed by Russia. The ones that materialised were a general preliminary examination into the situation in eastern Ukraine by the OTP ICC, coupled with domestic proceedings by the Netherlands specially set up for bringing the individuals behind MH17 to trial. Alternatively, proposals drew inspiration from concluding agreements between the UN and a State, instituting a tribunal $a$ la Lockerbie, or initiating efforts at the UNGA, by which the pronouncements of the UNSC would be avoided (see Matta 2015b; Pillai 2019).

On the basis of the conclusions of the OVV and JIT investigations, the Dutch Public Prosecution Service (OM) initiated proceedings against individuals allegedly cooperating closely on obtaining and deploying the BUK TELAR in March 2020, as explained by Matta 
(2017). Four suspects - Igor Girkin, Sergey Dubinskiy, Oleg Pulatov and Leonid Kharchenko - are prosecuted with causing the crash of flight MH17 and the murder of 298 persons on board, with the Court in session at the time of writing and a hearing on the merits expected in June 2021. The Prosecutor decided not to bring charges for war crimes, which Lachezar Yanev deemed a strategic choice so as to "avoid unnecessary debates" and circumvent the implications of applying international humanitarian law (2020).

In parallel, the situation in eastern Ukraine had been under preliminary examination at the ICC from April 2014 until December 2020. Given that Ukraine is not a State Party to the Rome Statute, it accepted ICC's jurisdiction re crimes allegedly committed on its territory from 20 February 2014 onwards, including the MH17 incident by way of a second declaration in September $2015^{60}$. In its Report on Preliminary Activities 2018, the OTP confirmed the classification of the situation in eastern Ukraine in April 2014 as a non-international armed conflict between Ukraine and armed groups, amongst which were DPR and LPR. Notwithstanding, the OTP recognised the existing inferences for the possible parallel existence of an international armed conflict between Russia and Ukraine, or alternatively the possible internationalization of the previously existing non-international armed conflict by Russia's exercise of overall control over the armed groups. Thus, the OTP decided to consider the alleged crimes pursuant to Rome Statute provisions which would apply regardless of the armed conflict classification (see Whiting 2014). With the examination having been concluded, the OTP's request that the Pre-Trial Chamber authorises an investigation should follow up at the $\mathrm{ICC}^{61}$.

\section{CONCLUDING OBSERVATIONS}

It is yet left to be seen how the multi-forum litigation strategy with regards the downing of MH17 will play out. Bearing in mind the parallel proceedings pursued in international fora, it can reasonably be presumed that future pronouncements of the courts will have

60 ICC. 2018. Report on Preliminary Examination Activities. $\$ \$ 59-62$. https:// www.icc-cpi.int/itemsDocuments/181205-rep-otp-PE-ENG.pdf (last visited 7 November 2020).

61 ICC. Preliminary Examination - Ukraine. https://www.icc-cpi.int/ukraine (last visited 14 February 2021). 
repercussions on the findings of one another and the pursuit for redress for the downing of MH17. Certainly, a preliminary issue forming a common basis to all procedures will be to clarify the convoluted facts surrounded by a politically charged context.

One line of future analyses will be the link established between the ICJ and the ECtHR, with the latter also striking the coherence between individual complaints and inter-State proceedings. While having proven a high degree of judicial integration in numerous fields, the MH17 incident brings to the forefront questions which could now perhaps become settled coherently between the two courts, such as the previously addressed scope of positive obligations owed by States, as well as its demarcation with complicity as a mode of culpability. As emphasized by Forowicz, the unity between the two courts is dictated by the degree of incorporation of human rights protection in general international law $(2015,215-217)$. Mindful of that, approaching the disputed notions in their jurisprudence whilst upholding human rights can not only lead to judicial integration between the two courts, but also propound the central role of the ICJ and prevent a fragmented international legal system.

Additionally, the course taken up for pursuing State responsibility will go hand-in-hand with those pursuing individual culpability. Indeed, the most evident field of overlap among the courts is the possible implications of shedding light on the relation between the separatist groups and Russia. And so, it will primarily rest upon the ICJ to disclose the nature of the activities of the separatist groups and the extent of Russia's knowledge thereof. In two instances, the ECtHR will bear the assessment of Russia's degree of control and authority over the activities in eastern Ukraine at the time, including the downing of MH17. It will also pronounce upon the continuous obligations of Ukraine in a separate case. Finally, domestic (and possibly international) criminal proceedings will bring the individual perpetrators behind the incident to the fore.

There is also merit in the parallel developments present outside the courtrooms. As highlighted by the UN Special Rapporteur on Extrajudicial, Summary or Arbitrary Killings in January 2021, this and similar cases unveiled the gaps in the legal framework governing aviation in circumstances of heightened tensions. Thus, a set of recommendations for situations where safety may be jeopardised incorporates the necessary steps of both airlines and states, coupled with 
a reactive role of the international community $(2021,2-5)$. When it comes to the preventive limb, the Special Rapporteur emphasises the need for establishing clear indicators on when the States obligation to close its airspace is triggered, installing accountability mechanisms for States choosing to act to the contrary and granting a more significant role in monitoring the safety of the airspace to appropriate international bodies (2021, 4-5). Post facto, efforts must be put into establishing impartial investigations, giving greater impetus to fact-finding and preventing impunity $(2021,7)$.

Seeking legal remedies for the downing of MH17 is a showcase example of the nature of the international rule of law. Certainly, access to judicial remedies on the international plane was recognised as part and parcel of the efforts to advance the international rule of law by the United Nations. Reflecting on the characteristics of the international rule of law presented by Crawford, the example of MH17 proceedings ensuing State responsibility could be deemed to mirror each one of them. It shows that the international legal framework recognises the formal equality of States, and thus does not contemplate questions of their relative political power in the right to bring proceedings before international courts. Likewise (and consequently), it strengthens the legal constraints imposed on authorities, not only in terms of both the negative and positive human rights obligations owed to individuals, but also with regards to their inter-State behaviour. Additionally, through pursuing cases in international fora and seeking the enforcement of erga omnes obligations enshrined in international law, a climate of accountability is fostered among States. Moreover, the preliminary wide theoretical debates embody the plurality of both treaty avenues and available mechanisms through which the international law provides for a possibility to remedy social injustice.

Ultimately, with international law being recognised as a system lacking hierarchy and vertical integration, the MH17 case challenges that paradigm. It raises pertinent questions of relations between different international courts, thus contributing the debate of a process of international constitutionalization and the ICJ's possible centrality in that system. So long as there is coordination amongst them, the proliferation of proceedings can defy concerns over a fragmented system without any direction. At present, the ground for MH17 is put in place in a variety of international bodies which have the chance to prove their unity, and thus, proper redress in the name of the victims of the tragic event. 


\section{REFERENCES}

1. BBC. 2014. MH17 crash: Airlines divert flights from eastern Ukraine. //www.bbc.com/news/business-28356745 (last visited 4 November 2020).

2. Chestermann, Simon. 2007. Rule of Law. in Max Planck Encyclopedia of Public International Law. Oxford Public International Law.

3. Chimni, S. Bhupinder. 2012. Legitimating the rule of law. 290-308 in The Cambridge Companion to International Law, edited by James Crawford and Martti Koskenniemi. Cambridge: Cambridge University Press.

4. Crawford, James. 2002. The International Law Commission's Articles on State Responsibility - Introduction, Text and Commentaries. Cambridge: Cambridge University Press.

5. Crawford, James. 2013a. Chance, Order, Change: The Course of International Law. The Hague: Pocketbooks of the Hague Academy of International Law.

6. Crawford, James. 2013b. State responsibility - The General Part. Cambridge: Cambridge University Press.

7. Crawford, James, Kenne, Amelia. 7/2020. Interpretation of the human rights treaties by the International Court of Justice. The International Journal of Human Rights. 24: 935-956.

8. De Hoon, Marieke, Julie Fraser, Brianne McGonigle Leyh. 2016. Legal Remedies for Downing Flight MH17. White Paper. Public International Law \& Policy Group and VU University Amsterdam. https://www.vu.nl/nl/ Images/Legal_Remedies_for_Downing_Flight_MH17_tcm289-747125.pdf (last visited 14 November 2020).

9. De Hoon, Marieke. 84/2017. Navigating the Legal Horizon: Lawyering the MH17 Disaster. Utrecht Journal of International and European Law 33: 90-119.

10. DW. 2020. Australia, Netherlands slam Russia's withdrawal from MH17 talks. https://www.dw.com/en/australia-netherlands-slam-russias-withdrawal-from-mh17-talks/a-55293316 (last visited 7 November 2020).

11. ECtHR. 2018a. ECHR to adjourn some individual applications on Eastern Ukraine pending Grand Chamber judgment in related inter-State case. Press Release.

12. ECtHR. 2018b. Extra-territorial jurisdiction of States Parties to the European Convention on Human Rights. Fact Sheet.

13. ECtHR. 2018c. Grand Chamber to examine four complaints by Ukraine against Russia over Crimea and Eastern Ukraine. Press Release.

14. ECtHR. 2019. ECHR gives notification to Russia of cases brought by relatives of people killed in the downing of Malaysian Airlines flight MH-17. Press Release. 
15. ECtHR. 2020a. New inter-State application brought by the Netherlands against Russia concerning downing of Malaysia Airlines fight MH17. Press Release.

16. ECtHR. 2020b. Practical Guide on Admissibility Criteria. \$88. (last visited 12 November 2020).

17. Forowicz, Magdalena. 2015. Factors influencing the reception of international law in the ECtHR's case law: an overview. 191-217 in A Farewell to Fragmentation: Reassertion and Convergence in International Law, edited by Mads Andenas and Eirik Bjorge. Cambridge: Cambridge University Press.

18. Garciandia, Rosana. 2020. State responsibility and positive obligations in the European Court of Human Rights: The contribution of the ICJ in advancing towards more judicial integration. Leiden Journal of International Law 33: 177-187.

19. Gibney, Mark. 1/2015. The Downing of MH17: Russian Responsibility? Human Rights Law Review 15: 169-178.

20. Government of the Netherlands. 2020. The Netherlands brings MH17 case against Russia before European Court of Human Rights. https://www. government.nl/latest/news/2020/07/10/the-netherlands-brings-mh17-caseagainst-russia-before-european-court-of-human-rights (last visited 12 November 2020).

21. Greenwood, Christopher. 2015. Unity and Diversity in International Law. 37-55 in A Farewell to Fragmentation: Reassertion and Convergence in International Law, edited by Mads Andenas and Eirik Bjorge. Cambridge: Cambridge University Press.

22. Heller, Kevin Jon. 2014. MH17 Should Be Framed as Murder, Not as a War Crime. Opinio Juris. https://opiniojuris.org/2014/08/11/mh-17-framedmurder-war-crime/ (last visited 13 November 2020).

23. Hill-Cawthorne, Lawrence. 2019. International Litigation and the Disaggregation of Disputes: Ukraine/Russia as a Case Study. ICLQ. 68: 779-815.

24. ICC. 2018. Report on Preliminary Examination Activities. \$\$59-62. https://www.icc-cpi.int/itemsDocuments/181205-rep-otp-PE-ENG.pdf (last visited 7 November 2020).

25. ILC. 2006. Fragmentation of International Law: Difficulties Arising from the Diversification and Expansion of International Law. Report of the Study Group of the International Law Commission, $58^{\text {th }}$ Session, A/ CN.4/L.682. https://legal.un.org/ilc/documentation/english/a_cn4_l682.pdf (last visited 12 November 2020).

26. Katselli Proukaki, Elena. 2010. The Problem of Enforcement in International Law - Countermeasures, the non-injured state and the idea of international community. London: Routledge Research in International Law.

27. Kontogiannis, Dimitris. 2019. Provisional Measures in Ukraine v. Russia: From Illusions to Reality or a Prejudgment in Disguise? EJIL:Talk! https:// www.ejiltalk.org/provisional-measures-in-ukraine-v-russia-from-illusionsto-reality-or-a-prejudgment-in-disguise/ (last visited 10 November 2020). 
28. Koskenniemi, Martti, Päivi Leino. 3/2002. Fragmentation of International Law? Postmodern Anxieties. Leiden Journal of International Law 15: 553-579.

29. Marchuk, Iryna. 2019. Green Light from the ICJ to Go Ahead with Ukraine's Dispute against the Russian Federation Involving Allegations of Racial Discrimination and Terrorism Financing. EJIL:Talk! https://www. ejiltalk.org/green-light-from-the-icj-to-go-ahead-with-ukraines-disputeagainst-the-russian-federation-involving-allegations-of-racial-discrimination-and-terrorism-financing/ (last visited 6 November 2020).

30. Matta, Aaron. 2015a. Guest Post: Malaysia Airlines Flight MH17 - Possible Legal Avenues for Redress (Part 1). Opinio Juris. https://opiniojuris. org/2015/08/27/guest-post-malaysia-airlines-flight-mh17-possible-legalavenues-for-redress-part-1/ (last visited 13 November 2020).

31. Matta, Aaron. 2015b. Guest Post: Malaysia Airlines Flight MH17 - Possible Legal Avenues for Redress (Part 2). Opinio Juris. https://opiniojuris. org/2015/08/28/guest-post-malaysia-airlines-flight-mh17-possible-legalavenues-for-redress-part-2/ (last visited 14 November 2020).

32. Matta, Aaron. 2017. MH17 Downing Suspects to be Prosecuted Before Dutch Domestic Courts - An Obstacle or an Advantage for International Justice? Opinio Juris. https://opiniojuris.org/2017/07/17/33212/ (last visited 12 November 2020).

33. Milanović, Marko. 2014. The Downing of MH17 and the Potential Involvement of International Courts. EJIL:Talk! https://www.ejiltalk.org/thedowning-of-mh17-and-the-potential-involvement-of-international-courts/ (last visited 14 November 2020).

34. Milanović, Marko. 2018. The Applicability of the ECHR in Contested Territories; Two Other ECHR Cases Against Russia. EJIL:Talk! https://www. ejiltalk.org/the-applicability-of-the-echr-in-contested-territories-two-otherechr-cases-against-russia/ (last visited 9 November 2020).

35. Milanović, Marko. 2019. Russian Agents Charged with Downing of MH17; MH17 Cases in Strasbourg. EJIL:Talk! https://www.ejiltalk.org/ russian-agents-charged-with-downing-of-mh17-mh17-cases-in-strasbourg/ (last visited 28 October 2020).

36. Milanović, Marko. 2021. ECtHR Grand Chamber Declares Admissible the Case of Ukraine v. Russia re Crimea. EJIL:Talk! https://www.ejiltalk.org/ ecthr-grand-chamber-declares-admissible-the-case-of-ukraine-v-russia-recrimea/ (last visited 14 February 2021).

37. Milanović, Marko, Sangeeta Shah. 2021. Ukraine and the Netherlands v. Russia (nos 8019/16, 43800/14 and 28525/20), Amicus Curiae Brief. SSRN https://papers.ssrn.com/sol3/papers.cfm?abstract_id=3775402 (last visited 8 February 2021).

38. Motoc, Iulia, Johann Justus Vasel. 2018. The ECHR and Responsibility of the State: Moving Towards Judicial Integration: A View from the Bench. 
199-212 in The European Convention on Human Rights and General International Law, edited by Anne van Aaken and Iulia Motoc. Oxford: Oxford University Press.

39. Netherlands Public Prosecution Office. MH17 - Prosecution and trial. https://www.prosecutionservice.nl/topics/mh17-plane-crash/prosecutionand-trial (last visited 9 February 2021).

40. Ohlin, Jens David. 2014. Control Matters: Ukraine \& Russia and the Downing of Flight MH17. Opinio Juris. http://opiniojuris.org/2014/07/23/controlmatters-ukraine-russia-downing-flight-17/ (last visited 28 October 2020).

41. Peters, Anne. 2017. "Vulnerability" versus "Plausibility": Righting or Wronging the Regime of Provisional Measures? Reflections on ICJ, Ukraine v. Russian Federation, Order of 19 April 2017. EJIL:Talk! https://www.ejiltalk.org/vulnerability-versus-plausibility-righting-or-wronging-the-regime-ofprovisional-measures-reflections-on-icj-ukraine-v-russian-federation-order-of-19-apr/ (last visited 2 November 2020).

42. Pillai, Priya. 2019. Accountability for Flight MH17: A Long and Winding Road. Opinio Juris. https://opiniojuris.org/2019/06/20/accountability-forflight-mh17-a-long-and-winding-road/ (last visited 15 November 2020).

43. Proulx, Vincent-Joel. 2017. 'Terrorism' at the World Court: Ukraine v Russia as an Opportunity for Greater Guidance on Relevant Obligations? EJIL:Talk! -guidance-on-relevant-obligations/ (last visited 14 November 2020).

44. Pusztai, David. 2014. MH17 Goes to Strasbourg: Some Remarks on Obligations of Prevention, Foreseeability and Causation. EJIL:Talk! https:// www.ejiltalk.org/mh-17-goes-to-strasbourg-some-remarks-on-obligations-ofprevention-foreseeability-and-causation/ (last visited 12 November 2020).

45. Risini, Isabella, Geir Ulfstein. 2020. The Netherlands' inter-State application against Russia six years after MH17. EJIL:Talk! https://www.ejiltalk. org/the-netherlands-inter-state-application-against-russia-six-years-after$m h-17 /$ (last visited 23 September 2020).

46. Risini, Isabella. 2018. The Inter-State Application under the European Convention on Human Rights - Between Collective Enforcement of Human Rights and International Dispute Settlement. Leiden: Brill Nijhoff.

47. Spielmann, Dean. 2015. Fragmentation or Partnership? The Reception of ICJ Case-law by the European Court of Human Rights. 173-190 in A Farewell to Fragmentation: Reassertion and Convergence in International Law, edited by Mads Andenas and Eirik Bjorge. Cambridge: Cambridge University Press.

48. The Guardian. 2014. Many airlines have avoided Ukrainian airspace for months. https://www.theguardian.com/world/2014/jul/18/airlines-avoidukraine-airspace-mh17 (last visited 4 November 2020). 
49. The Guardian. 2018. MH17: Australia and Netherlands accuse Russia of complicity. https://www.theguardian.com/world/2018/may/25/mh17-australia-and-netherlands-accuse-russia-of-complicity (last visited 14 November 2020).

50. The Netherlands Public Prosecution Service. The criminal investigation by the Joint Investigative Team (JIT). https://www.prosecutionservice.nl/ topics/mh17-plane-crash/criminal-investigation-jit-mh17 (last visited 12 November 2020).

51. Trapp, Kimberley. 2017. Ukraine v Russia (Provisional Measures): State 'Terrorism' and IHL. EJIL:Talk! https://www.ejiltalk.org/ukraine-v-russiaprovisional-measures-state-terrorism-and-ihl/ (last visited 4 November 2020).

52. Ulfstein, Geir, Isabella Risini. 2020. Inter-State Applications under the European Convention on Human Rights: Strengths and Challenges. EJIL:Talk! (last visited 28 October 2020).

53. UN. 2015. Security Council Fails to Adopt Resolution on Tribunal for Malaysia Airlines Crash in Ukraine, Amid Calls for Accountability, Justice for Victims. UN Security Council $7498^{\text {th }}$ Meeting, SC/11990. https://www. un.org/press/en/2015/sc11990.doc.htm (last visited 5 November 2020).

54. UN. 2019. Report of the International Court of Justice 2018/19. United Nations General Assembly. Official Records, Seventy-fourth Session, Supplement No. 4. New York 2019. \$190. https://www.icj-cij.org/public/files/ annual-reports/2018-2019-en.pdf (last visited 25 October 2020).

55. UN Special Rapporteur on Extrajudicial, Summary or Arbitrary Killings. 2021. Statement: Commercial Airlines and Conflict Zones: Recommendations to strengthen air safety and prevent unlawful deaths. https://www. ohchr.org/Documents/Issues/Executions/StatementCommercialAirlinesConflictZones_Jan2021.pdf (last visited 6 February 2021).

56. Whiting, Alex. 2014. How to Prosecute the Perpetrators of the Malaysian Jet Downing. Just Security. https://www.justsecurity.org/13269/prosecuteperpetrators-malaysian-jet-downing/ (last visited 28 October 2020).

57. Yanev, Lachezar. 2020. The Dutch Prosecution's Opening Statement in the MH-17 Trial: What Lies Beyond the Horizon? EJIL:Talk! https://www. ejiltalk.org/the-dutch-prosecutions-opening-statement-in-the-mh-17-trial-what-lies-beyond-the-horizon/ (last visited 6 November 2020). 